\title{
Skin Wound Healing Effects and Action Mechanism of Acai Berry Water Extracts
}

\author{
Mi Hyun Kang' ${ }^{1}$ Seunghye Choi ${ }^{2}$ and Bae-Hwan Kim \\ ${ }^{1}$ Major in Public Health, Faculty of Food and Health Sciences, Keimyung University, Daegu, Korea \\ ${ }^{2}$ College of Pharmacy, Ewha Womans University, Seoul, Korea
}

(Received December 30, 2016; Revised February 27, 2017; Accepted March 2, 2017)

\begin{abstract}
The purpose of this study was to investigate the wound healing effect of acai berry water extracts (ABWE) and a possible underlying mechanism involved in its action using various in vitro and in vivo models. The wound healing effect of ABWE was evaluated by migration assay using HS68 fibroblast cells. In addition, its effect on mRNA expression of procollagen, fibronectin, and MMP-1 was determined. Moreover, the wound healing effect of ABWE was evaluated in in vivo wound models through macroscopic and microscopic observation. In addition, mRNA expression levels of wound related genes were determined. Results revealed that ABWE was not cytotoxic. It increased migration of HS68 fibroblast cells. ABWE increased mRNA expression levels of fibronectin but decreased the mRNA expression levels of MMP-1. ABWE also showed significantly potent wound healing effect in vivo based on macroscopic and histopathological observation and mRNA expression evaluation for wound related genes. Taken together, our results indicated that ABWE might have potential as a wound healing agent.
\end{abstract}

Key words: Wound healing, Acai berry, Skin, Action mechanism

\section{INTRODUCTION}

Wound is defined as abnormal structure or function of the human body due to trauma or disease. It has various molecular-level symptoms (1). Wound healing in the skin is a very complex phenomenon involving several processes. Many factors are involved in the normal process of wound healing (2). As a defensive mechanism to protect the human body from harmful materials (3), wound healing generally consists of three phases: inflammation, proliferation, and remodeling (4). Various types of rat models such as cut wound (5) and extraction wound (6) have been used to study wound healing.

Inflammation period is the time from damage to prompt response. During this period, wound will activate platelet to secret fibronectin and fibrin (7). Activated platelets may coagulate blood and secret growth factors such as platelet-

Correspondence to: Bae-Hwan Kim, Major in Public Health, Faculty of Food and Health Sciences, Keimyung University, Daegu 42601, Korea

E-mail: kim9399@kmu.ac.kr

This is an Open-Access article distributed under the terms of the Creative Commons Attribution Non-Commercial License (http:// creativecommons.org/licenses/by-nc/3.0) which permits unrestricted non-commercial use, distribution, and reproduction in any medium, provided the original work is properly cited. derived growth factor (PDGF) and transforming growth factor- $\beta$ (TGF- $\beta$ ) (8). In the initial phase of inflammation, monocytes secret cytokines and growth factors such as interleukin-1, tumor necrosis factor- $\alpha$ (TNF- $\alpha)$, TGF- $\beta$, and PDGF. These cytokines and growth factors will cause infiltration of inflammatory cells which play important roles in infiltration, multiplication, and synthesis of collagen fibers (9). Mast cells are known to play important roles in the wound healing process. They secrete histamine that increases the penetrability of blood vessels and the migration of inflammatory cells. Mast cells are involved in the formation of new blood vessels and re-absorption of extracellular matrix (10).

Proliferative stage refers to the time for the formation of granulation tissue by macrophages or fibroblasts surrounding the wound. Angiogenesis, collagen deposition, epithelialization, and wound contraction are observed at this stage (11). Fibroblasts can synthesize collagen and form the connective tissue. They play important roles in wound contraction during wound healing under the influence of fibrin and fibronectin (12). Collagen is a very highly functional element in the process of wound healing. Usually, type I collagen accounts for about $80 \%$ of total collagen (7). Fibronectin is involved in adhesion between tissues and cells or between cells (13). It can induce cell migration associated with the reconstruction of an organism in the process of wound heal- 
ing (14). Matrix metalloproteinases (MMPs) play an important role in controlling extracellular matrix contents in the damaged organism. MMP-1 is an extracellular matrix protease involved in re-formation of connective tissues in the wound healing process by inducing degradation of extracellular matrix proteins such as collagen, fibronectin, and laminin in the extracellular matrix (15).

Remodeling phase is the final stage of wound healing. New collagen is synthesized by TGF- $\beta$. Scar of damaged tissue is minimized and restored to its original status by prompt regeneration. It is important functionally and aesthetically.

Various studies have attempted to enhance wound healing effect, especially for medical-related treatment. However, only some studies have reported that herb extracts can be used as natural medicine without side effects, unlike synthetic chemicals that are currently used for wound healing (16).

Acai berry (Euterpe oleracea Mart.) is a purple fruit of a palm tree. It contains lots of anthocyanin and polyphenolic compounds. It has been reported that acai berry has excellent suppressing effect on the generation of reactive oxygen species (ROS) (17). It can suppress the activation of cyclooxygenase-2 (COX-2) and TNF- $\alpha$ in vitro (18). These results have confirmed that acai berry is effective in controlling oxidation and inflammatory reactions. However, little is known about the wound healing effect of acai berry or its action mechanisms.

Therefore, the objective of this study was to assess the in vitro and in vivo effect of acai berry extracts containing various bioactive ingredients on wound healing process of skin and determine its potential as an alternative wound healing agent.

\section{MATERIALS AND METHODS}

Reagents and preparation of acai berry water extracts (ABWE). Dulbecco's modified Eagle Medium (DMEM), fetal bovine serum (FBS), and penicillin/streptomycin (P/S) were obtained from Lonza (Walkersville, MD, USA). 4-[3(4iodophenyl)-2-(4-nitrophenyl)-2H-5-tetrazolio]-1,3-benzene disulfonate (WST-1) was obtained from Roche (Cascade, CA, USA).

Freeze-dried powder (organic acai berry powder 99.9\% and citric acid $0.1 \%$ ) of acai berry (Sambazon, Paragon laboratories, Torrance, CA, USA) was purchased from Korean agency. ABWE was prepared by depositing $100 \mathrm{~g}$ of acai berry powder in $1 \mathrm{~L}$ of water of $80^{\circ} \mathrm{C}$ and extracted for $3 \mathrm{hr}$. It was then filtered and freeze-dried for $72 \mathrm{hr}$. These extraction processes were repeated three times to obtain ABWE for the present study.

Enzyme inhibitory activity. Elastase inhibitory activity was measured by detecting $p$-nitroaniline released during the hydrolysis of substrate N-Succinyl-(L-Ala)3-p-nitroanilide (19). Absorbance was measured at wavelength of 445 $\mathrm{nm}$. The percentage of inhibition was calculated using the following equation:

$$
\text { Inhibition rate }(\%)=\left[1-\left(\mathrm{A}_{\text {sample }} / \mathrm{A}_{\text {control }}\right)\right] \times 100
$$

Where $\mathrm{A}_{\text {control }}$ was the absorbance of the control (reagents without the test compounds).

Collagenase inhibitory activity was measured according to the method of Wünsch and Heindric (20). Percentage of collagenase inhibitory activity was calculated using the following equation:

$$
\begin{array}{r}
\text { Collagenase inhibitory activity }(\%) \\
=(1-(\mathrm{A}-\mathrm{B}) /(\mathrm{C}-\mathrm{D})) \times 100
\end{array}
$$

Where A was absorbance at $320 \mathrm{~nm}$ determined for test sample with enzyme; B was absorbance at $320 \mathrm{~nm}$ determined for buffer instead of enzyme; $\mathrm{C}$ was absorbance at $320 \mathrm{~nm}$ determined for buffer instead of test sample; and D was absorbance at $320 \mathrm{~nm}$ determined for buffer instead of test sample and enzyme.

Cell viability and migration assay. Human normal fibroblast cells (HS68, ATCC, American Type Culture Collection) were cultured in Dulbecco's modified Eagle's medium (DMEM) containing 10\% fetal bovine serum (FBS) and $1 \%$ penicillin/streptomycin $(\mathrm{P} / \mathrm{S})$ at $37^{\circ} \mathrm{C}$ in a $5 \% \mathrm{CO}_{2}$ incubator.

Viability of cultured cells was determined with WST-1 assay. Briefly, cells $\left(1 \times 10^{4}\right)$ were distributed into 96-well cell culture plates and incubated for $24 \mathrm{hr}$. They were then treated with $\mathrm{ABWE}$ at concentration of $0,0.1,0.3$, or $1 \mathrm{mg} /$ $\mathrm{mL}$. The medium of cells was then removed. WST-1 solution diluted in PBS at a ratio of $1: 10$ was then reacted with cells in the dark for $3 \mathrm{hr}$ in an incubator $\left(37^{\circ} \mathrm{C}\right)$. The absorbance value was measured at wavelength of $450 \mathrm{~nm}$. Percentage of cell viability was calculated using the following equation:

$$
\% \text { cell viability }=\left(\mathrm{A}_{\text {sample }} / \mathrm{A}_{\text {control }}\right) \times 100
$$

To determine the influence of ABWE on migration of HS68 cells, cells were distributed into 6-well plates at $1 \times 10^{5}$ cells/well and cultivated for $24 \mathrm{hr}$ in DMEM containing by $10 \%$ FBS. A single cell layer was scratched after pre-incubation at $37^{\circ} \mathrm{C}$ for $24 \mathrm{hr}$ by using a $200 \mu \mathrm{L}$ plastic micropipette tip. Test material was then added at indicated concentrations followed by incubation in the $\mathrm{CO}_{2}$ incubator for $24 \mathrm{hr}$. Photographs of wounded area were taken using a phase-contrast microscope.

Measurement of genetic expression of HS68 cells. Extracted total RNA (1250 ng) was reverse transcribed into cDNA using pre-master mix with oligo dT (Bioelpis, Seoul, Korea). Real-time PCR was done using cDNA as template to measure mRNA expression of specific genes. cDNA $(1 \mu \mathrm{L})$ was added to $12.5 \mu \mathrm{L}$ of $2 \times$ SYBR Green PCR Mas- 
Table 1. Sequence of primers used for real-time PCR of in vitro study

\begin{tabular}{|c|c|c|c|}
\hline Genes & & Primers & Amplicon size $(b p)^{1)}$ \\
\hline \multirow{2}{*}{ Type I-procollagen } & Forward $\left(5^{\prime} \rightarrow 3\right)$ & GCT TCA CCT ACA GCG TCA CT & \multirow{2}{*}{306} \\
\hline & Reverse $\left(5^{\prime} \rightarrow 3^{\prime}\right)$ & AAG CCG AAT TCC TGG TCT GG & \\
\hline \multirow{2}{*}{$\mathrm{MMP}-1^{2)}$} & Forward $\left(5^{\prime} \rightarrow 3^{\prime}\right)$ & GAT GTG GAG TGC CTG ATG TG & \multirow{2}{*}{298} \\
\hline & Reverse $\left(5^{\prime} \rightarrow 3^{\prime}\right)$ & TGC TTG ACC CTC AGA GAC CT & \\
\hline \multirow{2}{*}{ Fibronectin } & Forward $\left(5^{\prime} \rightarrow 3^{\prime}\right)$ & ACT CTG ACA GGC CTC ACC A & \multirow{2}{*}{478} \\
\hline & Reverse $\left(5^{\prime} \rightarrow 3^{\prime}\right)$ & GTG TAG GGG TCA AAG CAC GA & \\
\hline \multirow{2}{*}{$\beta$-Actin } & Forward $\left(5^{\prime} \rightarrow 3^{\prime}\right)$ & AAT CTG GCA CCA CAC CTT CTA C & \multirow{2}{*}{318} \\
\hline & Reverse $\left(5^{\prime} \rightarrow 3^{\prime}\right)$ & ATA GCA CAG CCT GGA TAG CAA C & \\
\hline
\end{tabular}

${ }^{1)} \mathrm{bp}$, basepair; ${ }^{2} \mathrm{MMP}-1$, matrix metalloproteinase-1.

ter Mix, $1.5 \mu \mathrm{L}$ of $5 \mu \mathrm{M}$ sense and antisense primer, and $8.5 \mu \mathrm{L}$ of distilled water to obtain a final volume of $25 \mu \mathrm{L}$. Real time PCR was then performed using Applied Biosystems 7300 real-time PCR System (Applied Biosystems, Waltham, MA, USA). Primer sequences of $\beta$-actin, type 1procollagen, MMP-1, and fibronectin are listed in Table 1.

\section{In vivo skin wound healing experiment.}

Animals and experimental group: Six-week-old male Sprague Dawley (SD) rats $(180 \sim 200 \mathrm{~g})$ were obtained from Daehan biolink (Eumsung, Korea) and acclimatized for one week. They were then assigned to each group. The animal room was maintained at temperature of $22 \pm 3^{\circ} \mathrm{C}$, humidity of $50 \pm 10 \%$, and $12 \mathrm{hr}$ of light-and-dark cycle per day. They were provided free ad libitum access to food (Purina, Korea) and water for the experiment period. Experimental protocol and animal care were in accordance with the guidelines of the Institutional Animal Care and Use Committee (IACUC) of Keimyung University (Daegu, Korea). Five animals were assigned to each group with a randomized block design. For the vehicle control group (VC), 2\% of carboxymethyl cellulose (CMC) was applied. For the positive control group (PC), commercially available ointment containing $20 \mathrm{mg} / \mathrm{g}(2 \%)$ of sodium fusidate was applied. For ABWE treatment groups, 1\% ABWE (E1), 3\% ABWE (E2), or 5\% ABWE (E3) was applied.

Design of skin wound model: Excision wound model was prepared according to previous methods (21) with slight modifications. Briefly, hair in the pertinent area of animals for both experimental and control groups were removed using electric clipper. Iodine tincture was then applied on the skin to disinfect the epidermis. Four circular wounds at $20 \mathrm{~mm}$ in diameter were then made on two skin places that were $2 \mathrm{~cm}$ away outwards from the vertebra using No. 11 surgical scalpels. After making wounds, the cut part was covered with sterilized and disinfected gauze for dressing to induce secondary healing. Each of the five groups had five animals. Test material $(200 \mu \mathrm{L})$ was then applied to the wound area once a day for 18 days until complete epithelialization. After applying the test material, the wound was covered by sterilized gauze. Then an additional $100 \mu \mathrm{L}$ of the test material was applied to the top of the gauze to minimize external contact. The treated area was banded with non-irritant tape for one day. The positive control group received $150 \mathrm{mg}$ of $2 \%$ sodium fusidate.

Measurement of clinical index and macroscopic observation of wound area. Clinical signs, water intake, and food intake were measured daily at 10 am throughout the study period. To observe the wound healing process, photos of dermal wounds were taken at $0,6,12$, and 18 days after application of the test material using a digital camera for each group before applying the test material again. Sections were graded subjectively for skin restoration as: no lesion (grade 0); mild (grade 1); moderate (grade 2), and severe (grade 3 ).

Histopathological observation of tissue. After finishing the experiment, the skin tissue of wound area was fixed in $10 \%$ neutral formalin solution for $24 \mathrm{hr}$. It was then embedded in paraffin through a common process of water charge, dehydration, hyaline, and permeation. The embedded tissue was then cut into pieces of $4 \mu \mathrm{m}$ in thickness and stained with hematoxylin and eosin (H\&E) to observe changes in dermal tissue such as thickness of epidermis or permeation of inflammatory cells. The embedded tissue was also stained with toluidine blue to observe the distribution of mast cells or Masson's trichrome to observe changes in dermal collagen through optical microscopy (Leica, Wetzlar, Germany).

Measurement of gene expression level in skin tissue. Total RNA was isolated from the removed skin tissue with Trizol solution $(800 \mu \mathrm{L})$. It was then used for cDNA synthesis. RT-PCR was performed using the synthetized cDNA as template to measure expression levels of specific genes. RT-PCR reaction contained $1 \mu \mathrm{L}$ of cDNA, $2 \mu \mathrm{L}$ of $\mathrm{dNTP}$, $2 \mu \mathrm{L}$ of Taq buffer, $0.2 \mu \mathrm{L}$ of Taq DNA polymerase, $0.5 \mu \mathrm{L}$ of forward primer, and $0.5 \mu \mathrm{L}$ of reverse primer. The total reaction volume was $20 \mu \mathrm{L}$. Primer sequences for $\beta$-actin, type 1-collagen, VEGF, MMP-1, fibronectin, IL-1 $\beta$, and TNF- $\alpha$ are listed in Table 2. PCR reaction solution was then 
Table 2. Sequence of primers used for RT-PCR of in vivo study

\begin{tabular}{|c|c|c|c|}
\hline Genes & & Primers & Amplicon size $(b p)^{1)}$ \\
\hline \multirow{2}{*}{ Type 1-collagen } & Forward $\left(5^{\prime} \rightarrow 3^{\prime}\right)$ & TTC TCC TGG TAA AGA TGG TGC & \multirow{2}{*}{254} \\
\hline & Reverse $\left(5^{\prime} \rightarrow 3^{\prime}\right)$ & TGT TAA AGG TGA TGC TGG TCC & \\
\hline \multirow{2}{*}{ VEGF $^{2)}$} & Forward $\left(5^{\prime} \rightarrow 3^{\prime}\right)$ & CAT GCG GAT CAA ACC TCA CC & \multirow{2}{*}{515} \\
\hline & Reverse $\left(5^{\prime} \rightarrow 3^{\prime}\right)$ & CCT CCG GAC CCA AAG TGC TC & \\
\hline \multirow{2}{*}{$\mathrm{MMP}^{3)}$} & Forward $\left(5^{\prime} \rightarrow 3^{\prime}\right)$ & TGG GAT TTC CAA AAG AGG TG & \multirow{2}{*}{121} \\
\hline & Reverse $\left(5^{\prime} \rightarrow 3^{\prime}\right)$ & ACG TGG TTC CCT GAG AAG A & \\
\hline \multirow{2}{*}{ Fibronectin } & Forward $\left(5^{\prime} \rightarrow 3^{\prime}\right)$ & AGC TCA TCA GCA TCC AGC AG & \multirow{2}{*}{255} \\
\hline & Reverse $\left(5^{\prime} \rightarrow 3^{\prime}\right)$ & ACT GTG GCT CAT CTC CCT CC & \\
\hline \multirow{2}{*}{ IL-1 $\beta$} & Forward $\left(5^{\prime} \rightarrow 3^{\prime}\right)$ & GAA GTC AAG ACC AAA GTG G & \multirow{2}{*}{542} \\
\hline & Reverse $\left(5^{\prime} \rightarrow 3^{\prime}\right)$ & TGA AGT CAA CTA TGT CCC G & \\
\hline \multirow{2}{*}{ TNF- $\alpha^{4)}$} & Forward $\left(5^{\prime} \rightarrow 3^{\prime}\right)$ & ATC TTC TCG AAC CCC GAG TG & \multirow{2}{*}{51} \\
\hline & Reverse $\left(5^{\prime} \rightarrow 3^{\prime}\right)$ & GGG TTT GCT ACA ACA TGG GG & \\
\hline \multirow{2}{*}{$\beta$-Actin } & Forward $\left(5^{\prime} \rightarrow 3^{\prime}\right)$ & CAC CCG CGA GTA CAA CCT TC & \multirow{2}{*}{207} \\
\hline & Reverse $\left(5^{\prime} \rightarrow 3^{\prime}\right)$ & CCC CAT ACC CAC CAT CAC ACC & \\
\hline
\end{tabular}

${ }^{11} \mathrm{bp}$, basepair; ${ }^{2} \mathrm{VEGF}$, vascular endothelial growth factor; ${ }^{3)} \mathrm{MMP}-1$, matrix metalloproteinase-1; ${ }^{4} \mathrm{TNF}-\alpha$, tumor necrosis factor $\alpha$.

subjected to $2 \%$ agarose gel electrophoresis at 100 volts for $30 \mathrm{~min}$ in $1 \times$ TAE buffer $(40 \mathrm{mM}$ Tris, $20 \mathrm{mM}$ acetate $\mathrm{pH}$ 8.1, 2 mM EDTA). Expected PCR bands were checked based on a DNA size marker.

Statistical analysis. Data are presented as means \pm standard deviation (SD) of means. Statistically significant difference between groups were identified by Student's $t$ test at $p<0.05, p<0.01$, and $p<0.001$ for in vitro test and by one-way analysis of variance (ANOVA) followed by
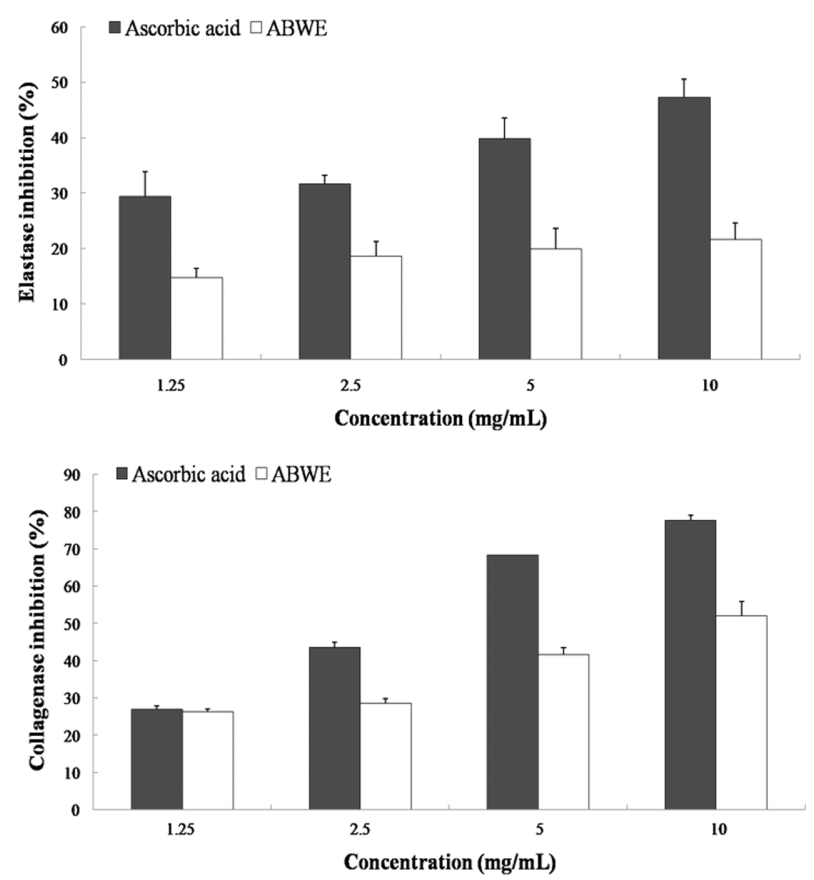

Fig. 1. Inhibition effect of $A B W E$ on elastase and collagenase activity. Values represent the means \pm SD of three independent measurements. ABWE: Acai berry water extract.
Duncan's multiple-range test at $p<0.05$ for in vivo results. All statistical analyses were performed using SPSS 21.0 for windows (IBM, Armonk, NY, USA).

\section{RESULTS}

Enzyme activity of ABWE. Elastase inhibition efficacy of $\mathrm{ABWE}$ at $10 \mathrm{mg} / \mathrm{mL}$ was $21.5 \%$, which was lower than that $(47.56 \%)$ of control vitamin $\mathrm{C}$ (ascorbic acid) at the same concentration. Collagenase inhibitory efficacy of ABWE at

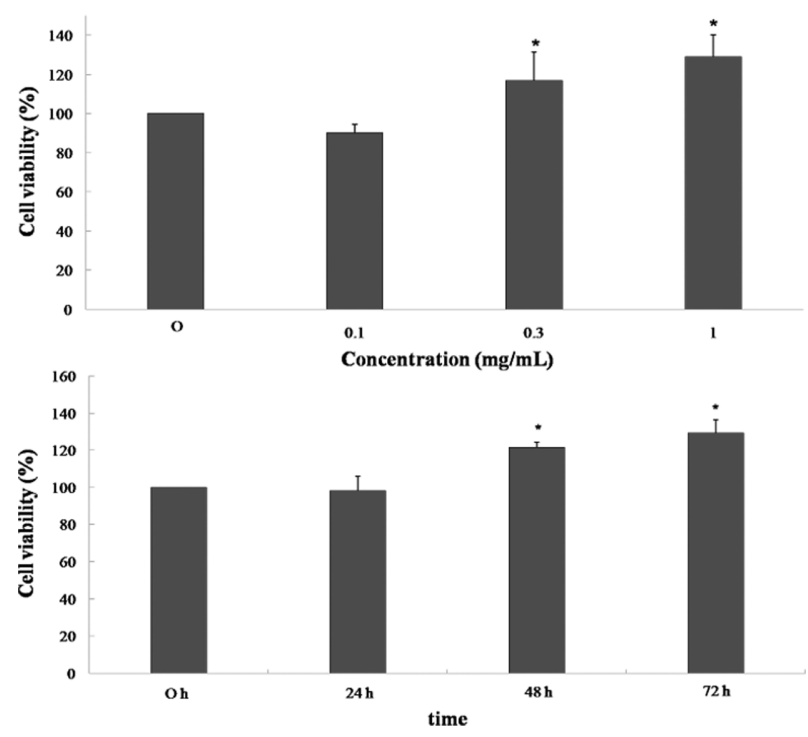

Fig. 2. Effect of ABWE on HS68 cells proliferation. Viabilities of HS68 cells were measured after treatment with ABWE at different concentrations $(0,0.1,0.3$, and $1 \mathrm{mg} / \mathrm{mL})$ for $72 \mathrm{hr}$ or at different time points $(0,24,48$, and $72 \mathrm{hr})$ after treatment with ABWE based on WST-1 assay. Values represent the means \pm SD of three independent measurements. ${ }^{*} p<0.05$. ABWE: Acai berry water extract. 


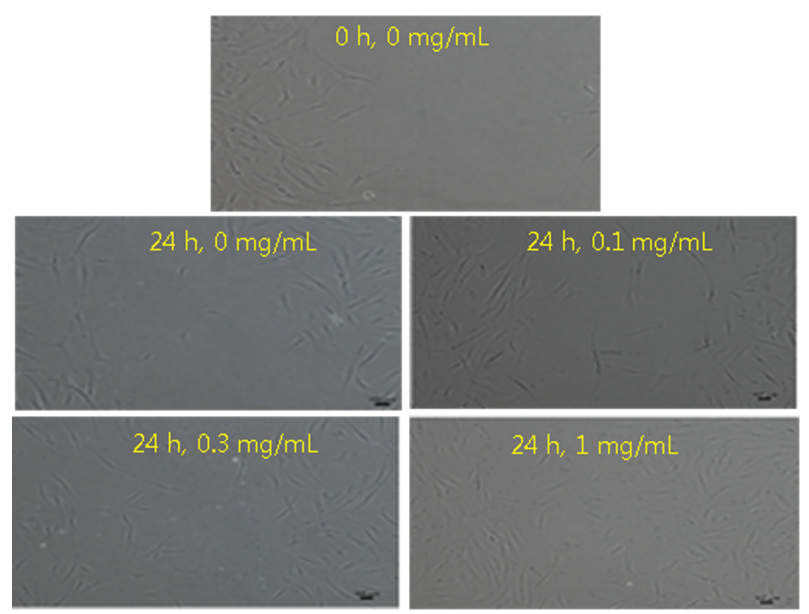

Fig. 3. Effect of ABWE on HS68 cell migration. Monolayers of confluent HS68 cells were wounded with plastic micropipette tips. HS68 cells were treated with indicated concentrations of ABWE. HS68 cells were photographed at $24 \mathrm{hr}$ after wounding by light microscopy. ABWE: Acai berry water extract.

$10 \mathrm{mg} / \mathrm{mL}$ was $56.4 \%$, which was lower than that $(87.5 \%)$ of control vitamin $\mathrm{C}$ (ascorbic acid) at the same concentration (Fig. 1).

Cell proliferation and migration assay. Cytotoxicity of ABWE to HS 68 cells was evaluated by WST-1 assay. Results showed that ABWE had no cytotoxicity to HS68 cells up to its effective concentration (less than $1 \mathrm{mg} / \mathrm{mL}$ ). $\mathrm{ABWE}$ at 0.3 and $1 \mathrm{mg} / \mathrm{mL}$ significantly promoted cell

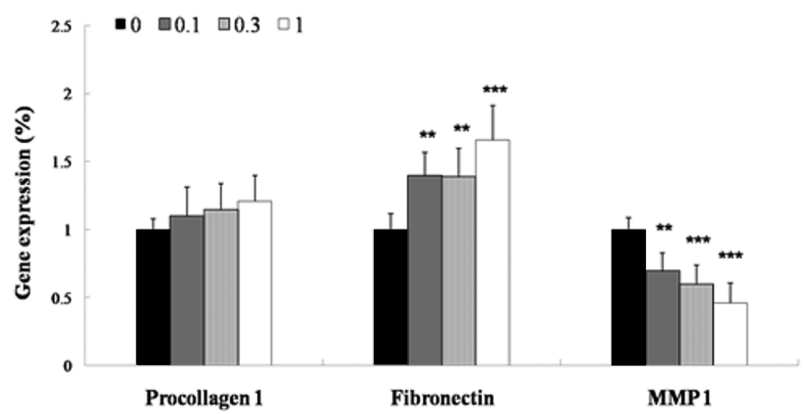

Fig. 4. Effect of $A B W E$ on mRNA expression levels of type I procollagen, fibronectin, and MMP-1 in HS68 cells. mRNA expression levels of type I procollagen, fibronectin, and MMP-1 in cells treated with test material $\operatorname{ABWE}(0,0.1,0.3$, and $1 \mathrm{mg} / \mathrm{mL})$ for $72 \mathrm{hr}$ was analyzed by real-time RT-PCR. Values are means \pm SD of three independent measurements. ${ }^{* *} p<0.01$; ${ }^{* * *} p<0.001$. ABWE: Acai berry water extract.

proliferation in a dose-dependent manner. ABWE also enhanced cell proliferation in a time-dependent manner. Numbers of HS68 cells cultured for $48 \mathrm{hr}$ and $72 \mathrm{hr}$ in the presence of $1 \mathrm{mg} / \mathrm{mL}$ of ABWE were significantly $(p<$ 0.05 ) increased compared to those without treatment with ABWE (Fig. 2).

Cell migration plays an important role in wound healing. Therefore, scratch wound assays were performed to study the effect of ABWE on HS68 cells. Results showed that $\mathrm{ABWE}$ treated groups had more active cell migration to the scratched area than those without ABWE treatment (Fig. 3).

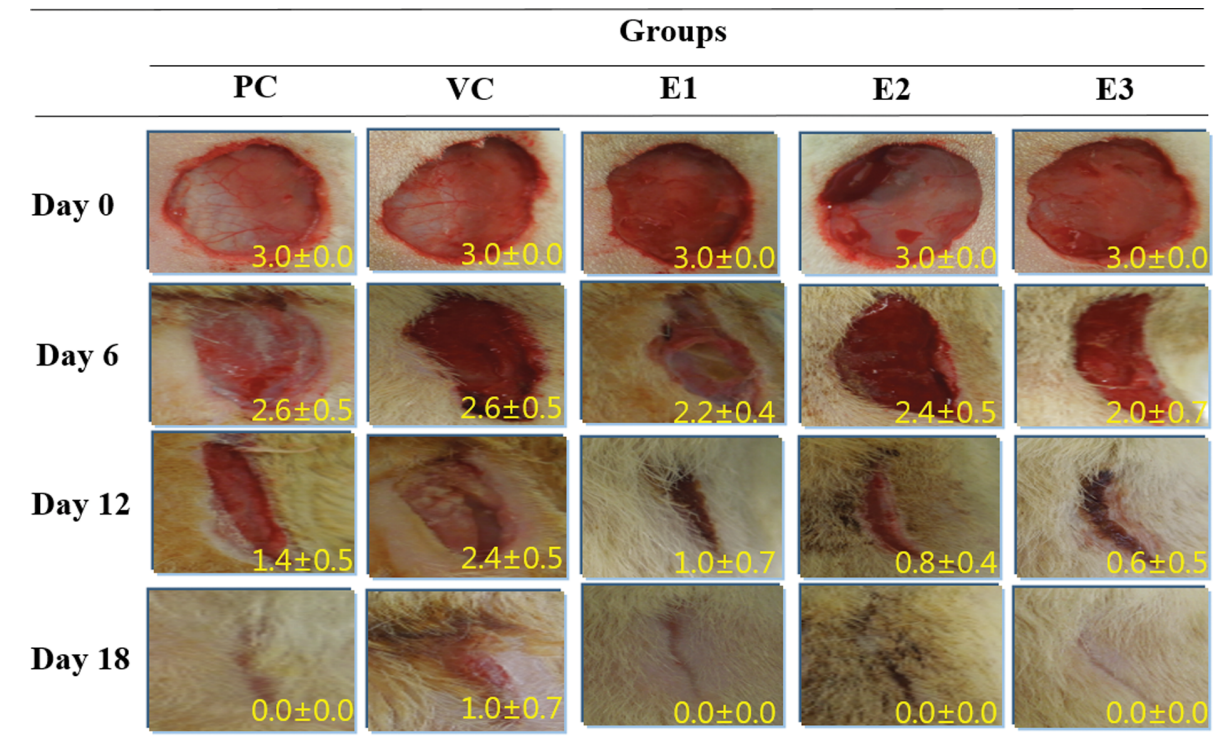

Fig. 5. Macroscopic observations of excision wounds at the skin. Changes in skin appearance of PC, VC, E1, E2, or E3 treated-rats on day $0,6,12$, and 18 post-wounding. Wound areas treated with ABWE were reduced on day 6,12 , and 18 . Values are means \pm SD of five independent measurements (grade 0: normal, grade 1: minimal, grade 2: moderate, and grade 3: severe). PC: $2 \%$ sodium fusidate, VC: $2 \%$ carboxymethyl cellulose (CMC), E1: 1\% ABWE, E2: 3\% ABWE, E3: 5\% ABWE. ABWE: Acai berry water extract. 


\begin{tabular}{|c|c|c|c|c|c|}
\hline & \multicolumn{5}{|c|}{ Groups } \\
\hline & $\mathbf{P C}$ & VC & E1 & E2 & E3 \\
\hline H\&E & & & & & \\
\hline $\begin{array}{l}\text { Toluidine } \\
\text { Blue }\end{array}$ & & & & & \\
\hline $\begin{array}{c}\text { Masson's } \\
\text { Trichrome }\end{array}$ & & & & & \\
\hline
\end{tabular}

Fig. 6. Microscopical examination of skin $(\times 100)$. Histological appearance of wounds from experimental groups by H\&E, Toluidine blue, and Masson's trichrome staining on day 18 after wounding. PC: $2 \%$ sodium fusidate, VC: $2 \%$ carboxymethyl cellulose (CMC), E1: $1 \%$ ABWE, E2: 3\% ABWE, E3: 5\% ABWE. ABWE: Acai berry water extract.

Real-time RT-PCR results of mRNAs in HS68 cells. Fibronectin mRNA expression levels were significantly upregulated by ABWE. However, MMP-1 mRNA levels were significantly down-regulated by ABWE (Fig. 4).

In vivo wound healing experiment. There was no statistically significant difference in clinical signs, water intake, or feed intake among treatment groups. Each group displayed acute inflammatory changes around the wound area (Fig. 5). Wound size changed on day 6 after wound was made. Wound area was found to become smaller and restored in ABWE treated group (especially in E3) on day 18 compared to that in the vehicle control treated group.

Histopathological observation of tissue. In ABWE applied groups, inflammation was recovered with improved alignment of epidermis and thick skin compared to vehicle control treated group based on skin H\&E staining. Based on toluidine blue staining results, the number of mast cells of the vehicle control treated group was significantly more than that of group treated with ABWE. ABWE treated group displayed higher concentrations of collagen with regular alignment compared to vehicle control treated group based on Masson's trichrome staining (Fig. 6).

RT-PCR results of skin. Expression levels of type I collagen, VEGF, and fibronectin mRNAs were increased in ABWE treated groups compared to those in vehicle control treated group. However, mRNA expression levels of MMP1 and IL- $1 \beta$ were decreased in ABWE treated group compared to those in vehicle control treated group (Fig. 7).

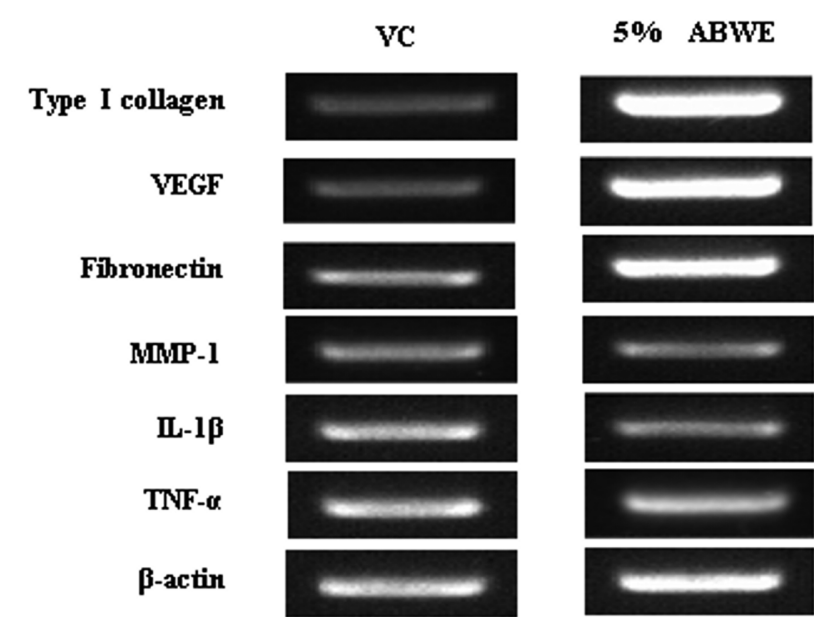

Fig. 7. Effect of $A B W E$ on mRNA expression levels of some genes in skin. mRNA expression levels of type I collagen, VEGF, fibronectin, MMP-1, IL-1 $\beta$, and TNF- $\alpha$ in rats skin were determined at day 18 after excisional wound. ABWE: 5\% acai berry water extract.

TNF- $\alpha$ expression levels were similar to each other among different treatment groups.

\section{DISCUSSION}

Results of this study showed that ABWE did not cause cell toxicity in in vitro study. Scratch assay has been recognized as a direct and economic way to assess wound healing in vitro (22). After assessing the effect of ABWE on cell migration, it was found that the scratch wound healed more 
rapidly after $24 \mathrm{hr}$ of $\mathrm{ABWE}$ treatment compared to that in vehicle control treated group.

Results of in vitro studies showed that ABWE was a useful material for wound healing. It is well known that growth factor and cytokines play important roles in the process of wound healing. Fibronectin is involved in coagulation, epithelial cell movement, cell differentiation, collagen matrix assembly, and wound contraction in the process of wound healing (23). Significantly $(p<0.01)$ greater expression of fibronectin was observed in ABWE treated group compared to that in vehicle control treated group. Such increase in fibronectin expression was dependent on the concentration of ABWE. Significantly $(p<0.01)$ less expression of MMP-1 was observed in ABWE treated group compared to that in vehicle control treated group. Such decrease in MMP-1 expression was also dependent on the concentration of ABWE. This indicates that ABWE can promote cell migration but reduce MMP-1 expression, thus influencing collagen synthesis.

The skin wound healing effect of ABWE was then assessed using in vivo animal model through macroscopic and histopathological observation and examination of gene expression change. Groups treated by ABWE were found to have significantly reduced wound area at 6 days after creating the wound compared to the vehicle control group. On day 18 after creating the skin wound, all groups showed reepithelization.

Wound healing begins with inflammation and exudate secretion. After that, inflammation is suppressed, leading to re-epithelization and wound contraction (4). In this experiment, ABWE treated groups showed faster healing compared to vehicle control treated group. Based on this result, application of ABWE is expected to aid rapid wound healing. This might be due to the fact that acai berry has strong anti-inflammatory ingredients such as anthocyanin and antioxidant ingredients.

ABWE treated groups had thinner and smoother epidermis on day 18 after creating the wound compared to vehicle control treated group. Based on the observation that ABWE encourages the most prompt regeneration of tissue, permeation of production of collagen might have enhanced the speed of wound healing.

It has been reported that mast cells control the initial inflammation reaction by infiltrating white blood cells, increasing vascular permeability, and composing cellulose (24). This study showed that ABWE treated groups had minimally reduced numbers of mast cells compared to vehicle control treated group. ABWE might be related to mast cells at the time of wound healing because mast cells are involved in the control of initial inflammatory reaction. In addition, mast cells can release many inflammatory mediators. They are involved in chronic inflammatory reactions (25).

In the group treated with 5\% ABWE, mRNA expression levels of type I collagen, VEGF, and fibronectin were found to be increased while MMP-1 and IL-1 $\beta$ mRNA levels were decreased. Based on Masson's trichrome staining, collagen accumulation was also found in ABWE treated groups. VEGF is expressed at low level in normal skin. However, its expression is increased in keratinocytes in the process of wound healing (26). In this study, VEGF mRNA expression was increased in ABWE treated groups, indicating that ABWE could stimulate the formation of new blood vessels to promote wound healing. TGF- $\beta$ is involved in the formation of granulation tissue at the re-epithelization stage through differentiation and proliferation of fibroblasts (27). IL-1 $\beta$ can activate $\mathrm{T}$ cells and increase the permeation of inflammatory cells such as lymphocytes or monocytes (28). A decrease in the expression of IL-1 $\beta$ mRNA indicates that ABWE is effective in healing wounds by inducing antiinflammatory reactions. MMP-1 is known as a collagenase. Its expression is increased significantly during inflammation or wound healing (29). With respect to MMP-1, a decrease in its expression at mRNA level indicates that ABWE is effective in healing wounds by decreasing collagenase. It has been reported that acai berry can suppress TNF- $\alpha$ in vitro (18). However, the expression level of TNF- $\alpha$ was not changed by acai berry treatment in this study. This might be due to the fact that severe inflammatory reactions can greatly induce TNF- $\alpha$ excretion, thus interfering with wound healing (30).

In summary, results of this study confirmed that ABWE had potential as a wound healing material by regulating factors related to wound healing as seen in both in vitro and in vivo experiments. Hence, this study is valuable since it presents a basis for the effect of ABWE on wound healing. However, additional studies such as clinical tests are needed in the future before using $\mathrm{ABWE}$ as a material for wound healing.

\section{REFERENCES}

1. Muralidhar, A., Babu, K.S., Sankar, T.R., Reddanna, P. and Latha, J. (2011) Evaluation of wound healing properties of bioactive fractions from the extract of Butea monosperma (lam) stem bark. Int. J. Phytomed., 3, 41-49.

2. Velnar, T., Bailey, T. and Smrkolj, V. (2009) The wound healing process: an overview of the cellular and molecular mechanisms. J. Int. Med. Res., 37, 1528-1542.

3. Woodley, D.T., O'Keefe, E.J. and Prunieras, M. (1985) Cutaneous wound healing: a model for cell-matrix interactions. $J$. Am. Acad. Dermatol., 12, 420-433.

4. Clark, R.A. (1993) Regulation of fibroplasia in cutaneous wound repair. Am. J. Med. Sci., 306, 42-48.

5. Ehrlich, H.P. and Hunt, T.K. (1968) Effects of cortisone and vitamin A on wound healing. Ann. Surg., 167, 324-328.

6. Morton, J.J. and Malone, M.H. (1972) Evaluation of vulneray activity by an open wound procedure in rats. Arch. Int. Pharmacodyn. Ther., 196, 117-126.

7. Robson, M.C., Steed, D.L. and Franz, M.G. (2001) Wound healing: biologic features and approaches to maximize heal- 
ing trajectories. Curr. Probl. Surg., 38, 72-140.

8. Kirsner, R.S. and Eaglstein, W.H. (1993) The wound healing process. Dermatol. Clin., 11, 629-640.

9. Park, J.E. and Barbul, A. (2004) Understanding the role of immune regulation in wound healing. Am. J. Surg., 187, 11S$16 \mathrm{~S}$.

10. Schechter, N.M., Brass, L.F., Lavker, R.M. and Jensen, P.J. (1998) Reaction of mast cell proteases tryptase and chymase with protease activated receptors (PARs) on keratinocytes and fibroblasts. J. Cell. Physiol., 176, 365-373.

11. Nayak, B.S. and Pinto Pereira, L.M. (2006) Catharanthus roseus flower extract has wound-healing activity in Sprague Dawley rats. BMC Complement. Altern. Med., 6, 41.

12. Diegelmann, R.F. and Evans, M.C. (2004) Wound healing: an overview of acute, fibrotic and delayed healing. Front. Biosci., 9, 283-289.

13. Repesh, L.A., Fitzgerald, T.J. and Furcht, L.T. (1982) Fibronectin involvement in granulation tissue and wound healing in rabbits. J. Histochem. Cytochem., 30, 351-358.

14. Katow, H., Yazawa, S.Y. and Sofuku, S. (1990) A fibronectinrelated synthetic peptide, Pro-Ala-Ser-Ser, inhibits fibronectin binding to the cell surface, fibronectin-promoted cell migration in vitro, and cell migration in vivo. Exp. Cell Res., 190, 17-24.

15. Nagase, H., Visse, R. and Murphy, G. (2006) Structure and function of matrix metalloproteinases and TIMPs. Cardiovasc. Res., 69, 562-573.

16. Park, S.T., Kim, J.W., Jeong, S.H. and Seo, Y.M. (2012) The effect of extract from several herbs grown naturally in Namwon province on wound treatment. J. Korean Biol. Nurs. Sci., 14, 122-128.

17. Kang, J., Li, Z., Wu, T., Jensen, G.S., Schauss, A.G. and Wu, X. (2010) Anti-oxidant capacities of flavonoid compounds isolated from acai pulp (Euterpe oleracea Mart.). Food Chem., 122, 610-617.

18. Fragoso, M.F., Prado, M.G., Barbosa, L., Rocha, N.S. and Barbisan, L.F. (2012) Inhibition of mouse urinary bladder carcinogenesis by açai fruit (Euterpe oleraceae Martius) intake. Plant Foods Hum. Nutr., 67, 235-241.

19. Cannell, R.J., Kellam, S.J., Owsianks, A.M. and Malker, J.M. (1988) Results of a large scale screen of microalgae for the production of protease inhibitors. Planta Med., 54, 10-14.

20. Wünsch, E. and Heindrich, H.G. (1963) Zur quantitativen bes- timmung der kollagenase. Hoppe Seylers Z. Physiol. Chem., 333, 149-151.

21. Tramontina, V.A., Machado, M.A., Nogueira Filho Gda, R., Kim, S.H., Vizzioli, M.R. and Toledo, Sd. (2002) Effect of bismuth subgallate (local hemostatic agent) on wound healing in rats. Histological and histometric findings. Braz. Dent. J., 13, 11-16.

22. Liang, C.C., Park, A.Y. and Guan, J.L. (2007) In vitro scratch assay: a convenient and inexpensive method for analysis of cell migration in vitro. Nat. Protoc., 2, 329-333.

23. Brown, L.F., Dubin, D., Lavigne, L., Logan, B., Dvorak, H.F. and Van de Water, L. (1993) Macrophages and fibroblasts express embryonic fibronectins during cutaneous wound healing. Am. J. Pathol., 142, 793-801.

24. Wershil, B.K., Murakami, T. and Galli, S.J. (1988) Mast celldependent amplification of an immunologically nonspecific inflammatory response. 1988. Mast cells are required for the full expression of cutaneous acute inflammation induced by phorbol 12-myristate 13-acetate. J. Immunol., 140, 2356-2360.

25. Metcalfe, D.D., Baram, D. and Mekori, Y.A. (1997) Mast cells. Physiol. Rev., 77, 1033-1079.

26. Nissen, N.N., Polverini, P.J., Koch, A.E., Volin, M.V., Gamelli, R.L. and DiPietro, L.A. (1998) Vascular endothelial growth factor mediates angiogenic activity during the proliferative phase of wound healing. Am. J. Pathol., 152, 1445-1452.

27. Shah, M., Revis, D., Herrick, S., Baillie, R., Thorgeirson, S., Ferguson, M. and Roberts, A. (1999) Role of elevated plasma transforming growth factor-betal levels in wound healing. Am. J. Pathol., 154, 1115-1124.

28. Mori, L., Iselin, S., De Libero, G. and Lesslauer, W. (1996) Attenuation of collagen-induced arthritis in $55-\mathrm{kDa}$ TNF receptor type 1 (TNFR1)-IgG1-treated and TNFR1-deficient mice. J. Immunol., 157, 3178-3182.

29. Zucker, S., Pei, D., Cao, J. and Lopez-Otin, C. (2003) Membrane type-matrix metalloproteinases (MT-MMP). Curr. Top. Dev. Biol., 54, 1-74.

30. Ashcroft, G.S., Jeong, M.J., Ashworth, J.J., Hardman, M., Jin, W., Moutsopoulos, N., Wild, T., McCartney-Francis, N., Sim, D., McGrady, G., Song, X.Y. and Wahl, S.M. (2012) Tumor necrosis factor-alpha (TNF- $\alpha)$ is a therapeutic target for impaired cutaneous wound healing. Wound Repair. Regen., 20, 38-49. 